\title{
RELATIONSHIP OF NITRATE AND PHOSPHATE CONCENTRATION ON PHYTOPLANKTON PRIMARY PRODUCTIVITY IN DUMAI RIVERS OF RIAU PROVINCE
}

\author{
Syafrizal ${ }^{1}$, Irvina Nurrachmi ${ }^{1}$, Efriyeldi $^{1}$ \\ ${ }^{1}$ Department of Marine Science, Faculty of Fisheries and Marine Universitas Riau, Pekanbaru \\ *syafrijal210195@gmail.com
}

\begin{abstract}
This research was conducted in January 2020 in the waters of the Sembilan Dumai River which aims to determine the concentration of nitrate and phosphate on the primary productivity of phytoplankton. The research method used in this research is the survey method while the determination of the research station was done by technic purposive sampling. The results showed that the average nitrate concentration ranged from $0.0194-$ $0.0749 \mathrm{mg} / \mathrm{l}$ and the average phosphate concentration ranged from $0.1452-0.8502 \mathrm{mg} / \mathrm{l}$. There are 6 classes of phytoplankton found in the waters of the Sembilan Dumai River, namely Bacillariophyceae, Cocinodiscophyceae, Chroococcophyceae, Cyanophyceae, Cyanobacteria and Xanthophyceae. The results of phytoplankton abundance calculations ranged from 74.07 - $280.09 \mathrm{Ind} / \mathrm{L}$. The primary productivity value of phytoplankton for gross primary productivity ranged from $62.5-104.16 \mathrm{mgC} / \mathrm{m}^{2} / \mathrm{jam}$, respiration values ranged from $20.83-41.66 \mathrm{mgC} / \mathrm{m}^{2} / \mathrm{jam}$ and the net primary productivity value ranged from $41.67-72.91$ $\mathrm{mgC} / \mathrm{m}^{2} / \mathrm{jam}$. The results of the multiple linear regression test for the relationship between nitrate and phosphate on the primary productivity of phytoplankton at each station are shown by the mathematical equation $\mathrm{Y}=60.18+(-233,19,35) \mathrm{x}$ and $\mathrm{Y}=60.18+30.44 \mathrm{x}$ with the coefficient of determination $(\mathrm{R} 2)=0.140$ and $(\mathrm{R} 2)=0.226$ and the correlation coefficient $(\mathrm{r})$ $=0.631$, the mathematical equation states that the relationship between nitrate and phosphate on the primary productivity of phytoplankton is strong.
\end{abstract}

Keywords: Nitrate, Phosphate, Phytoplankton, and Primary Productivity

\section{PENDAHULUAN}

Nitrat merupakan unsur hara yang penting dalam perairan, unsur hara ini digunakan pada beberapa proses seperti fotosintesis, sintesis dari protein, dan sebagai penyusun gen serta pertumbuhan dari organisme. Nitrat adalah bentuk utama nitrogen di perairan dan merupakan nutrient utama yang dibutuhkan bagi pertumbuhan tanaman dan alga. Nitrat mudah larut dalam air dan bersifat stabil, sumber utama pengkayaan zat hara nitrat adalah run-off, erosi, lahan pertanian yang subur, dan limbah pemukiman, nitrat di perairan berasal dari pemecahan nitrogen organik dan anorganik dalam tanah yang berasal dari dekomposisi bahan organik dengan bantuan mikroba [1]. Fosfat adalah bentuk fosfor yang dapat dimanfaatkan oleh tumbuhan dan merupakan unsur esensial bagi tumbuhan tingkat tinggi dan alga sehimga dapat mempengaruhi tingkat produktivitas perairan. Sumber fosfor di perairan dan sedimen adalah defosit fosfor, industri, limbah domestik, aktivitas pertanian, pertambangan batuan fosfat, dan penggundulan hutan [2]. Produktivitas primer adalah kecepatan terjadinya proses 
fotosintesis atau peningkatan karbon dan produksi karbohidrat (zat organik) dalam satuan waktu dan volume tertentu. Produktivitas primer perairan merupakan salah satu faktor penting dalam ekosisitem perairan laut, karena berperan dalam siklus karbon dan rantai makanan untuk organisme heterotrop [3].

Perairan Sungai Sembilan Dumai terdapat 3 kelurahan yaitu keluraha Penyembal, kelurahan Basilam Baru yang memiliki kawasan hutan mangrove yang sebagian besar masih alami (natural based) memiliki potensi dan peluang untuk dijadikan kawasan ekowisata, kelurahan Lubuk Gaung merupakan kawasan yang paling banyak ditemukan industri, di perairan Lubuk Gaung dipadati dengan aktivitas transportasi laut. Perubahan kondisi suatu perairan dapat diakibatkan secara alami ataupun karena aktivitas manusia seperti air buangan dari kapal dan sebagainya yang menyebabkan menurunnya kualitas perairan. Penurunan kualitas perairan dapat mempengaruhi kandungan nitrat dan fosfat dengan produktivitas primer fitoplankton sehingga dapat berpengaruh terhadap pertumbuhan fitoplankton.

Permasalahan yang diangkat dalam hubungan konsentrasi nitrat dan fosfat dengan produktivitas primer fitoplankton di
Perairan Sungai Sembilan Dumai Provinsi Riau adalah bagaimana kondisi kualitas perairan, berapakah konsentrasi nitrat dan fosfat dengan produktivitas primer, berapakah tingkat produktivitas primer fitoplankton dan bagaimana hubungan nitrat dan fosfat terhadap produktivitas primer fitoplankton di Perairan Sungai Sembilan Dumai Provinsi Riau?

Adapun tujuan dan manfaat penelitian ini adalah untuk mengetahui konsentrasi nitrat dan fosfat terhadap produktivitas primer fitoplankton dan mengetahui hubungan kelimpahan fitoplankton terhadap konsentrasi nitrat dan fosfat di perairan Sungai Sembilan Dumai Provinsi Riau.

\section{METODE PENELITIAN Waktu dan Tempat}

Penelitian ini telah dilaksanakan pada bulan Januari 2020, pengambilan sampel dilakukan di perairan Sungai Sembilan Dumai Provinsi Riau (Gambar 1). Analisis nitrat dan fosfat dilakukan di Laboratorium Kimia Laut Jurusan Ilmu Kelautan Fakultas Perikanan dan Kelautan Universitas Riau sedangkan identifikasi fitoplankton dilakukan di Laboratorium Biologi Laut Jurusan Ilmu Kelautan Fakultas Perikanan dan Kelautan Universitas Riau.



Gambar 1. Peta Lokasi Penelitian 


\section{Metode Penelitian}

Metode yang digunakan dalam penelitian ini adalah metode survei yaitu pengamatan dan pengambilan sampel dilakukan secara langsung di lapangan.

\section{Prosedur Penelitian \\ Penentuan Lokasi dan Titik Sampling}

Penentuan stasiun pengamatan dilakukan secara purposive sampling, yaitu penentuan lokasi sampling dengan mempertimbangkan karakteristik berupa aktivitas yang diduga memberikan dampak di sekitar perairan. Lokasi penelitian dibagi ke dalam 3 (tiga) stasiun dimana stasiun I di Basilam Baru (kawasan Pelabuhan/ Tempat Penangkapan Ikan), stasiun II di Penyembal (kawasan Mangrove) dan stasiun III di Lubuk Gaung (Industri Minyak Kelapa Sawit).

\section{Pengambilan Sampel Air Nitrat dan Fosfat}

Pengambilan sampel air untuk analisis nitrat dan fosfat yaitu dengan menggunakan botol sampel. Sampel air diambil di permukaan sebanyak $300 \mathrm{ml}$ pada saat air laut pasang menggunakan kapal motor dan pada sampel air untuk analisis nitrat, sampel air diberi pengawet dan menambahkan larutan asam sulfat pekat sebanyak 2 tetes. Lalu botol-botol tersebut dibungkus menggunakan aluminium foil selanjutnya diberi label dan dimasukkan ke dalam ice box untuk analisis di laboratorium [4].

\section{Pengambilan Sampel Fitoplankton}

Teknik Pengambilan sampel fitoplankton dilakukan dengan teknik purposive sampling dimana pengambilan sampel di lakukan dengan sampel air permukaan 100 liter diambil menggunakan ember dengan volume $16 \mathrm{~L}$ dan selanjutnya disaring menggunakan plankton net nomor 25 hingga diperoleh $100 \mathrm{ml}$, lakukan sebanyak 7 kali pengulangan. Sampel yang telah tersaring sebanyak $100 \mathrm{ml}$ dimasukkan ke dalam botol sampel. Sampel diawetkan dengan lugol 4\% sebanyak 7 tetes. Sampel yang telah dimasukkan ke dalam botol diberi label dan kemudian dimasukan ke dalam ice box. Sampel dibawa kedalam laboratorium untuk diidentifikasi menggunakan buku oleh [56].

\section{Pengukuran Kualitas Perairan}

Pengukuran kualitas perairan yang di ukur berupa suhu, kecerahan, kecepatan arus, salinitas, $\mathrm{pH}$ dan oksigen terlarut.

\section{Analisis Nitrat dan Fosfat}

Analisis konsentrasi nitrat dan fosfat dilakukan di Laboratorium Oseanografi Kimia Laut Fakultas Perikanan dan Kelautan Universitas Riau. Analisis merujuk pada [7]. Air sampel yang dianalisis disaring terlebih dahulu sebanyak $15 \mathrm{ml}$ menggunakan kertas saring Whattman No.42 kemudian dimasukkan ke dalam tabung reaksi. Sampel yang di dalam tabung reaksi diteteskan EDTA sebanyak 4 tetes kemudian disaring lagi menggunakan saringan Cd. Setelah disaring diteteskan 10 tetes asam sulfanilamide dan 10 tetes larutan naptilamid. Kemudian diperhatikan perubahan warna merah muda pada tabung reaksi, setelah itu tabung reaksi dimasukkan ke dalam spektrofotometer dengan panjang gelombang $410 \mathrm{~nm}$ untuk mengukur nilai nitrat.

Air sampel yang dianalisis disaring terlebih dahulu sebanyak 12,5 $\mathrm{ml}$ menggunakan kertas saring Whatman No.42 kemudian dimasukkan ke dalam tabung reaksi. Sampel yang di dalam tabung reaksi diteteskan 10 tetes Ammonium molibdat dan 10 tetes $\mathrm{SnCl}_{2}$ kemudian dihomogenkan. Setelah larutan homogen diperhatikan perubahan warna biru pada tabung reaksi, setelah itu tabung reaksi dimasukkan ke dalam spektrofotometer dengan panjang gelombang $410 \mathrm{~nm}$ untuk mengukur nilai fosfat. 


\section{Identifikasi Fitoplankton}

Cara menganalisis fitoplankton adalah dengan sampel air dibawa ke laboratorium untuk dianalisis. Metode yang digunakan untuk menghitung jumlah fitoplankton adalah metode sapuan. Pengamatan dilakukan sebanyak tiga kali pengulangan. Fitoplankton diamati menggunakan mikroskop olympus CX 21 dengan perbesaran 10x10 dan diidentifikasi menggunakan buku identifikasi [5-6]. Kelimpahan fitoplankton dinyatakan secara kuantitatif dalam jumlah ind/liter. Dihitung berdasarkan rumus:

Keterangan :

$$
N=Z x \frac{X}{Y} \times \frac{1}{V}
$$

$$
\begin{aligned}
\mathrm{N}= & \begin{array}{l}
\text { Kelimpahan individu fitoplankton } \\
\text { (ind } / \mathrm{L})
\end{array} \\
\mathrm{Z}= & \text { Jumlah individu fitoplankton } \\
\mathrm{X}= & \text { volume air sampel yang tersaring } \\
& (125 \mathrm{ml}) \\
\mathrm{Y}= & \text { Volume } 1 \text { tetes air }(0,06 \mathrm{ml}) \\
\mathrm{V}= & \text { Volume air yang disaring }(100 \mathrm{~L})
\end{aligned}
$$

\section{Produktivitas Primer Fitoplankton}

Cara yang umum dipakai dalam mengukur produktivitas primer dalam suatu perairan adalah dengan menggunakan botol gelap dan botol terang. Sampel air diambil pada titik stasiun dengan menggunakan ember, dipindahkan ke masing-masing botol gelap dan terang tanpa gelembung udara (bubling), sebelum diukur kadar DO nya dilakukan penenggelaman di perairan tersebut selama 4 jam dan untuk pengukuran DO awal langsung diukur dengan botol BOD/Winkler $100 \mathrm{ml}$, kemudian dilakukan pengukurannya menggunakan metode Winkler.

Prosedurnya yaitu sampel air ditambahkan $2 \mathrm{ml}$ larutan $\mathrm{MnSO}_{4}$ dan $2 \mathrm{ml}$ $\mathrm{NaOH}+\mathrm{KI}$ hingga terbentuk endapan cokelat. Selanjutnya ditambahkan larutan $\mathrm{H}_{2} \mathrm{SO}_{4}$ sebanyak $4 \mathrm{ml}$ dan dikocok hingga endapan hilang, hingga berubah menjadi warna kuning tua. Kemudian dipindahkan larutan ke dalam erlenmeyer sebanyak 50 $\mathrm{ml}$ dan ditambahkan 3 tetes amylum hingga terbentuk warna biru/gelap. Selanjutnya dititrasi dengan menggunakan buret yang telah berisi Na-thiosulfat $\left(\mathrm{Na}_{2} \mathrm{~S}_{2} \mathrm{O}_{3}\right) 0,025$ $\mathrm{N}$ hingga berubah menjadi bening dan dihitung berapa ml titrasi yang digunakan.

Menurut [8], pengukuran produktivitas primer dapat diketahui dengan rumus, yaitu:

$$
\begin{gathered}
P P B=\frac{(D O b t-D O a) \times 1000 \times 0,375}{t \times P Q} \\
P P K=\frac{(D O b t-D O b g) \times 1000 \times 0,375}{t \times P Q} \\
R=\frac{(D O a-D O b g) \times 1000 \times 0,375}{t \times P Q}
\end{gathered}
$$

Keterangan :

PPB $=$ Produktivitas Primer Bersih $\left(\mathrm{mgC} / \mathrm{m}^{2} / \mathrm{jam}\right)$

PPK = Produktivitas Primer Kotor $\left(\mathrm{mgC} / \mathrm{m}^{2} / \mathrm{jam}\right)$

$\mathrm{R}=$ Respirasi $\left(\mathrm{mgC} / \mathrm{m}^{2} / \mathrm{jam}\right)$

$\mathrm{PQ}=$ Koefisien fotosintesis $(1,2)$

$\mathrm{T}=$ Waktu (4 jam)

$\mathrm{DOa}=$ Kadar Oksigen diawal pengukura (mg/l)

DObt $=$ Kadar oksigen pada botol terang akhir pengukuran (mg/l)

DObg $=$ Kadar oksigen pada botol gelap akhir pengukuran (mg/l)

$1000=$ Konversi liter ke $\mathrm{m}^{2}$

$0,375=$ Koefisien konversi oksigen menjadi karbon (12/32)

\section{Analisis Data}

Semua data yang diperoleh akan disajikan dalam bentuk tabel dan grafik, kemudian dianalisis secara deskriptif untuk menggambarkan kelimpahan dan produktivitas primer. Selanjutnya, dilakukan uji regresi linier menggunakan Software Microsoft Excell 2010 untuk melihat ada atau tidaknya hubungan, bagaimana arah hubungan dan seberapa kuat hubungan antara dua variabel (varibel bebas dan variabel terikat). Persamaan yang digunakan, menurut [9]:

Keterangan :

$$
\mathbf{Y}=\mathbf{a}+\mathbf{b x}
$$




$$
\begin{array}{ll}
\mathrm{Y} & =\begin{array}{l}
\text { Variabel dependen (Nitrat } \\
\text { dan Fosfat) }
\end{array} \\
\mathrm{a} \text { dan } \mathrm{b}= & \begin{array}{l}
\text { Konstanta dan koefisien } \\
\text { regresi }
\end{array} \\
\mathrm{x} & =\begin{array}{l}
\text { Variabel independen } \\
\text { (produktivitas primer) }
\end{array}
\end{array}
$$

Untuk mengetahui kerapatan hubungannya digunakan koefisien korelasi (r) dimana nilai $\mathrm{r}$ berada antara $0-1$. Menuru [9], keeratan nilainya yaitu :

$$
\begin{array}{ll}
0,00-0,25 & =\text { Hubungan lemah } \\
0,26-0,50 & =\text { Hubungan sedang } \\
0,51-0,75 & =\text { Hubungan kuat }
\end{array}
$$

$0,76-1,00=$ Hubungan sangat kuat

\section{HASIL DAN PEMBAHASAN Parameter Kualitas Perairan}

Perubahan terhadap kualitas perairan erat kaitannya dengan potensi perairan dilihat dari kelimpahan dan komposisi fitoplankton, oleh sebab itu kualitas perairan selalu dijadikan dalam pendekatan tingkat kesuburan perairan [10]. Hasil pengukuran kualitas perairan pada setiap stasiun penelitian dapat dilihat pada Tabel 1.

Tabel 1. Hasil Pengukuran Parameter Kualitas Perairan

\begin{tabular}{lcccc}
\hline Parameter Kualitas & \multirow{2}{*}{ Perairan } & Satuan & \multicolumn{3}{c}{ Stasiun } \\
\cline { 3 - 5 } & & Stasiun I & Stasiun II & Stasiun III \\
\hline Suhu & $\mathrm{C}$ & 30 & 33 & 33 \\
Salinitas & $\mathrm{Ppt}$ & 31 & 31 & 31 \\
Kecerahan & $\mathrm{Cm}$ & 91,8 & 35 & 105 \\
$\mathrm{pH}$ & - & 7 & 7 & 7 \\
Oksigen Terlarut & $\mathrm{mg} / \mathrm{l}$ & 6 & 4,6 & 6 \\
Kecepatan Arus & $\mathrm{m} / \mathrm{det}$ & 0,99 & 3,50 & 0,38 \\
\hline
\end{tabular}

Tabel 1 dapat dilihat bahwa suhu perairan berkisar $30-33^{\circ} \mathrm{C}$, yang terendah terdapat pada Stasiun I dengan nilai $30^{\circ} \mathrm{C}$ dan yang tertinggi terdapat di Stasiun II dan Stasiun III dengan nilai $30^{\circ} \mathrm{C}$. Salinitas setiap stasiun memiliki nilai yang sama yaitu 31 ppt. Kecerahan rata-rata $35-105$ m. pH di setiap stasiun yaitu 7. Oksigen terlarut pada setiap stasiun berkisar antara $4,6-6 \mathrm{mg} / \mathrm{l}$ dengan nilai yang tertinggi terdapat pada stasiun I dan stasiun III sedangkan nilai yang terendah terdapat pada stasiun II. Untuk kecepatan arus berkisar $0,38-3,50 \mathrm{~m} /$ det dengan nilai terendah terdapat pada stasiun III sedangkan nilai tertingi terdapat pada stasiun II.

\section{Konsentrasi Nitrat dam Fosfat di Perairan Sungai Sembilan Dumai}

Zat hara merupakan zat yang diperlukan dan mempunyai pengaruh dalam proses dan perkembangan hidup organisme seperti fitoplankton. Rata-rata konsentrasi nitrat dan fosfat antar stasiun dapat dilihat pada Tabel 2.

Tabel 2. Rata-rata Konsentrasi Nitrat dan Fosfat (mg/l)

\begin{tabular}{ccc}
\hline Stasiun & $\begin{array}{c}\text { Konsentrasi } \\
\text { Nitrat }\end{array}$ & $\begin{array}{c}\text { Konsentrasi } \\
\text { Fosfat }\end{array}$ \\
\hline I & 0,0194 & 0,188 \\
II & 0,0499 & 0,1452 \\
III & 0,0749 & 0,8502 \\
\hline
\end{tabular}

Tabel 2 terlihat bahwa rata-rata konsentrasi nitrat tertinggi terdapat pada stasiun III dengan nilai $0,0749 \mathrm{mg} / \mathrm{l}$ dan terendah pada stasiun I dengan nilai 0,0194 $\mathrm{mg} / \mathrm{l}$. Konsentrasi fosfat tertinggi terdapat pada stasiun III dengan nilai $0,8502 \mathrm{mg} / \mathrm{l}$, dan terendah pada stasiun stasiun I dengan nilai $0,188 \mathrm{mg} / \mathrm{l}$.

Konsentrasi fosfat terendah terdapat di stasiun I dengan nilai $0,188 \mathrm{mg} / \mathrm{l}$ di kawasan sekitar pelabuhan tempat 
penangkapan ikan. Rendahnya konsentrasi fosfat pada stasiun ini karena daerah tersebut merupakan kawasan yang penung dengan aktivitas transportasi laut atau pun dapat di katakana penuh dengan aktivitas manusia. [12], menyatakan bahwa Kesuburan perairan berdasarkan kandungan fosfat ada tiga tingkat yaitu: $0,003-0,010$ $\mathrm{mg} / \mathrm{l}$ perairannya adalah oligotropik (kurang subur), 0,010 - 0,030 mg/l perairannya adalah mesotropik (kesuburan sedang), dan $0,03-0,10 \mathrm{mg} / \mathrm{l}$ perairannya adalah eutropik (kesuburan tinggi). Konsentrasi fosfat pada perairan Sungai Sembilan yang di dapat dengan nilai ratarata pada setiap stasiun adalah 0,3944 $\mathrm{mg} / \mathrm{l}$, maka berdasarkan pernyataan tersebut perairan Sungai Sembilan dapat di kategorikan ke dalam perairan eutrofik (kesuburan tinggi).

\section{Jenis Fitoplankton}

Berdasarkan hasil penelitian yang dilakukan pada perairan Sungai Sembilan Dumai ditemukan 16 spesies yang berasal dari 7 kelas. Dari 7 kelas yang ditemukan, jenis fitoplankton terbanyak berasal dari kelas Bacillariophyceae. Hal ini disebabkan kelas Bacillariophyceae mampu menyesuaikan diri dengan kondisi lingkungan di sekitarnya dan mempunyai kemampuan reproduksi yang tinggi dibandingkan dengan kelas lainnya. Hal ini sesuai dengan pendapat [12], kelas Bacillariophyceae merupakan kelas dengan jumlah marga dan kelimpahan tertinggi karena mempunyai kemampuan reproduksi yang tinggi dibandingkan kelas fitoplankton yang lain. Lebih jelas dapat dilihat pada Tabel 3 .

Tabel 3. Jenis Fitoplankton

\begin{tabular}{|c|c|c|c|c|c|}
\hline \multirow{2}{*}{ No } & \multirow{2}{*}{ Kelas } & \multirow{2}{*}{ Spesies } & \multicolumn{3}{|c|}{ Stasiun } \\
\hline & & & $\mathbf{I}$ & II & III \\
\hline 1 & \multirow{7}{*}{ Bacillariophyceae } & Synedra $\mathrm{sp}$ & + & - & + \\
\hline 2 & & Navicula $\mathrm{sp}$ & + & + & + \\
\hline 3 & & Pleurosigma $\mathrm{sp}$ & - & - & + \\
\hline 4 & & Skeletonema $\mathrm{sp}$ & + & - & - \\
\hline 5 & & Pinnularia sp & + & + & - \\
\hline 6 & & Rhopaloidea Gibba sp & + & - & - \\
\hline 7 & & Hantzchia sp & + & - & - \\
\hline 8 & \multirow{4}{*}{ Coscinodiscophyceae } & Isthmia $\mathrm{sp}$ & + & + & + \\
\hline 9 & & Rhizosolenia sp & + & - & - \\
\hline 10 & & Melosira $\mathrm{sp}$ & + & - & - \\
\hline 11 & & Cyclotella sp & + & - & - \\
\hline 12 & \multirow{2}{*}{ Chroococcophyceae } & Coelosphaerium $\mathrm{sp}$ & + & - & - \\
\hline 13 & & Dactylococcopsis sp & + & - & - \\
\hline 14 & Cyanophyceae & Calothrix sp & + & - & + \\
\hline 15 & Cyanobacteria & Gloeocapsa sp & + & - & - \\
\hline 16 & Xanthophyceae & Tribonema $\mathrm{sp}$ & + & - & - \\
\hline \multicolumn{3}{|c|}{ Jumlah Jenis/Spesies } & 15 & 3 & 5 \\
\hline
\end{tabular}

Pada Tabel 3 dapat dilihat spesies fitoplankton yang paling banyak ditemukan terdapat pada stasiun I dengan jumlah 15 spesies, dan paling sedikit ditemukan di stasiun II dengan jumlah 3 spesies. Adapun spesies yang paling mendominan pada semua stasiun yaitu: Navicula sp, Synedra sp dan Isthmia sp.

\section{Kelimpahan Fitoplankon}

Kelimpahan fitoplankton disuatu perairan selalu berubah seiring dengan 
perubahan-perubahan yang terjadi di lingkungan sekitarnya, dimana perairan yang mengandung fitoplankton dapat dikatakan perairan yang masih ada aktivitas organisme konsumen. Perbandingan kelimpahan fitoplankton pada masingmasing stasiun memperlihatkan bahwa pada setiap stasiun mempunyai kelimpahan yang berbeda. Kelimpahan fitoplankton pada masing-masing stasiun bervariasi. Nilai rata-rata kelimpahan fitoplankton yang ditemukan setiap stasiun di perairan Sungai Sembilan Dumai berkisar 74,07 280,09 Ind/L dengan rata-rata kelimpahan fitoplankton terendah ditemukan di stasiun II yaitu 74,07 Ind/L sedangkan rata-rata kelimpahan tertinggi di temukan di Stasiun I yaitu 280,09 Ind/L (Gambar 2).

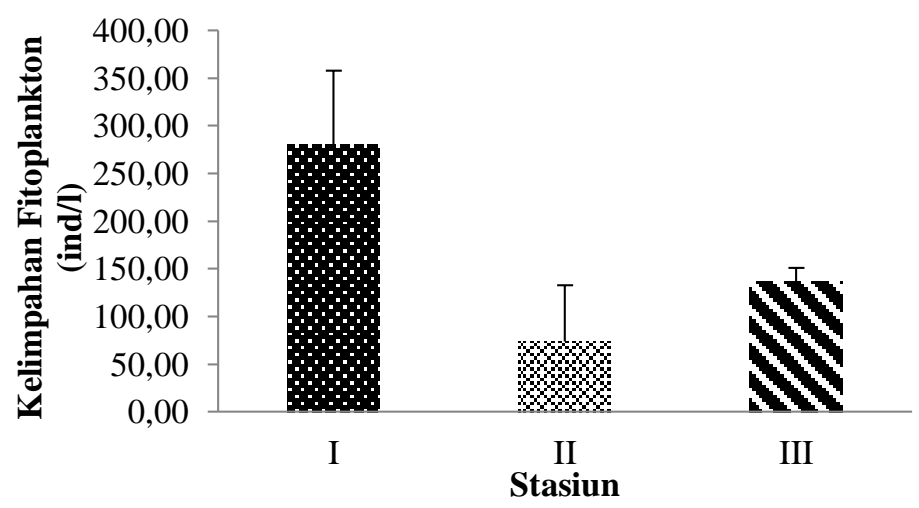

Gambar 2. Rata-rata Kelimpahan Fitoplankton (Ind/L)

[13] juga menemukan fitoplankton yang paling mendominansi di perairan Selat Bangka berasal dari kelas Bacillariophyceae, yakni dengan persentase sebanyak 98,33\%. Menurut [14] kelas Bacillariophyceae melimpah karena merupakan mikroalga uniseluler yang distribusinya sangat universal di semua tipe perairan. Fitoplankton memiliki bentuk kehidupan yang cosmopolit dan merupakan penyusun utama mikroalga baik di ekosistem perairan tawar maupun laut dengan jumlah spesies terbesar dibandingkan komunitas mikroalga lainnya.

[15] menyatakan bahwa perairan yang berada pada daerah sekitar mangrove merupakan area yang kaya nutrien baik organik maupun anorganik. Nutrien ini tidak hanya bermanfaat bagi mangrove, tetapi juga bermanfaat bagi pertumbuhan fitoplankton. Hal ini juga sejalan dengan pernyataan [16] yang menyatakan bahwa vegetasi mangrove sebagai nutrient trap dan pengendapan membuat konsentrasi fitoplankton serta unsur hara berada di permukaan dan mendukung terjadinya proses fotosintesis.

Tingginya nilai kelimpahan fitoplankton pada stasiun I juga diakibatkan masukan nutrien dari penguraian serasah mangrove oleh organisme renik perairan. Menurut [8] menyatakan bahwa, bagi produsen primer seperti fitoplankton, mangrove merupakan sumber nutrisi potensial melalui serasah mangrove. Selanjutnya [7] menyatakan serasah daun mangrove yang jatuh ke perairan akan mengalami dekomposisi dan mineralisasi yang akan memberikan tambahan nutrien. Serasah yang dihasilkan oleh tumbuhan mangrove (terutama dalam bentuk daun) merupakan sumber karbon dan nitrogen bagi hutan itu sendiri dan perairan disekitarnya. Parameter lingkungan yang mempengaruhi kehidupan dan perkembangan fitoplankton pada stasiun ini juga berada pada kisaran yang sesuai yaitu $\mathrm{pH}$, suhu, salinitas dan kecepatan arus berada pada nilai yang optimal untuk mendukung kehidupan fitoplankton. 


\section{Produktivitas Primer}

Menurut [18], Produktivitas primer menunjukkan Jumlah energi cahaya yang diubah menjadi energi kimia oleh autotrof suatu ekosistem selama suatu periode waktu tertentu. Untuk melihat nilai produktivitas primer di setiap stasiun maka dapat dilihat pada Tabel 4 .

Tabel 4. Rata-rata Tingkat Produktivitas Primer $\left(\mathrm{mgC} / \mathrm{m}^{2} / \mathrm{jam}\right)$ Fitoplankton

\begin{tabular}{cccc}
\hline Stasiun & Produktivitas Primer Kotor & Respirasi & Produktivitas Primer Bersih \\
\hline I & 104,16 & 31,25 & 72,91 \\
II & 62,5 & 20,83 & 41,67 \\
III & 104,16 & 41,66 & 62,5 \\
\hline
\end{tabular}

Tabel 4 dapat dilihat untuk nilai tertinggi pada produktivitas primer kotor terdapat pada stasiun I dan III dengan nilai $104,16 \mathrm{mgC} / \mathrm{m}^{2} / \mathrm{jam}$ dan nilai terendah pada produktivitas primer kotor terdapat pada stasiun II dengan nilai 62,5 $\mathrm{mgC} / \mathrm{m}^{2} /$ jam sedangkan nilai tertingi untuk produktivitas primer bersih terdapat pada stasiun I dengan nilai $72,91 \mathrm{mgC} / \mathrm{m}^{2} / \mathrm{jam}$ dan nilai terendah untuk produktivtas primer bersih terdapat pada stasiun II dengan nilai $41,67 \mathrm{mgC} / \mathrm{m}^{2} / \mathrm{jam}$.

Rata-rata hasil pengukuran produktivitas primer tertinggi terdapat pada stasiun I yaitu $72,91 \mathrm{mgC} / \mathrm{m}^{2} / \mathrm{jam}$. Jeppesen dalam [8] menyatakan bahwa produktivitas primer berkaitan dengan ketersediaan makanan, dimana peningkatan produktivitas primer akan diikuti oleh meningkatnya ketersediaan makanan. Jika fitoplankton meningkat dan intensitas cahaya matahari dapat menembus sebagian besar badan air, maka proses fotosintesis akan berlangsung dengan optimal. Jumlah fitoplankton melimpah maka akan mempengaruhi tingkat produktivitas primer di perairan. [14] menyatakan bahwa, terdapat hubungan positif antara kelimpahan fitoplankton dan produktivitas perairan. Jika kelimpahan fitoplankton di suatu perairan tinggi maka perairan tersebut cenderung memiliki produktivitas yang tinggi.

Rata-rata hasil pengukuran produktivitas primer terendah terdapat pada stasiun II yaitu $41,66 \mathrm{mgC} / \mathrm{m}^{2} / \mathrm{jam}$. Hal ini mungkin disebabkan karena daerah stasiun
II merupakan daerah yangpaling dalam diantara ketiga stasiun penelitian. Intensitas cahaya berkurang secara eksponsial sejalan dengan bertambahnya kedalaman air. Fotosintesis adalah proses mendasar dari produktivitas primer yaitu proses pembentukan bahan-bahan organik [19], sehingga jika perairan tersebut cukup dalam maka bahan organik dihasilkannya pun juga sedikit. Kandungan bahan organik sangat mempengaruhi produktivitas primer, sehingga daerah dengan kandungan bahan organiknya rendah akan mempunyai produktivitas primer rendah pula.

\section{Hubungan Konsentrasi Nitrat dan Fosfat terhadap Produktivitas Primer Fitoplankton \\ Dalam menganalisis hubungan} konsentrasi nitrat dan fosfat terhadap produktivitas primer fitoplankton digunakan metode analisis regresi linear berganda. Analisis ini digunakan karena mampu mengukur hubungan antara lebih satu variabel prediktor/variabel bebas. Sebelum dilakukan analisis regresi linear berganda terlebih dahulu dipastikan data yang ada sudah melewati uji asumsi kelasik (normalitas).

Hasil uji regresi linear berganda hubungan konsentrasi nitrat dan fosfat terhadap produktivitas primer fitoplankton di setiap stasiun ditunjukkan dengan persamaan matematis $\mathrm{Y}=60,18-233,19 \mathrm{x}$ dan $\mathrm{Y}=60,18+30,44 \mathrm{x}$ dengan nilai koefesien determinasi $\left(R^{2}\right)=0,140$ dan $\left(R^{2}\right)$ $=0.226$ dan koefesien korelasi $(\mathrm{r})=0,631$. 
Persamaan matematis menyatakan hubungan konsentrasi nitrat dan fosfat terhadap produktivitas primer fitoplankton adalah kuat. Nilai $r$ menyatakan hubungan yang kuat antara kandungan nitrat dan fosfat dengan Produktivitas Primer fitoplankton di perairan Sungai Sembilan. Berdasarkan hasil uji regresi linear tersebut, dapat diketahui pengaruh konsentrasi nitrat dan fosfat terhadap produktivitas primer fitoplankton sebesar $63,1 \%$ sementara $36,9 \%$ dipengaruhi oleh faktor lingkungan lainnya seperti faktor fisika (suhu, salinitas, dan kecepatan arus), kimia perairan ( $\mathrm{pH}$, DO, nitrat, fosfat dan silikat), dan biologi (mangrove) (Gambar 3).

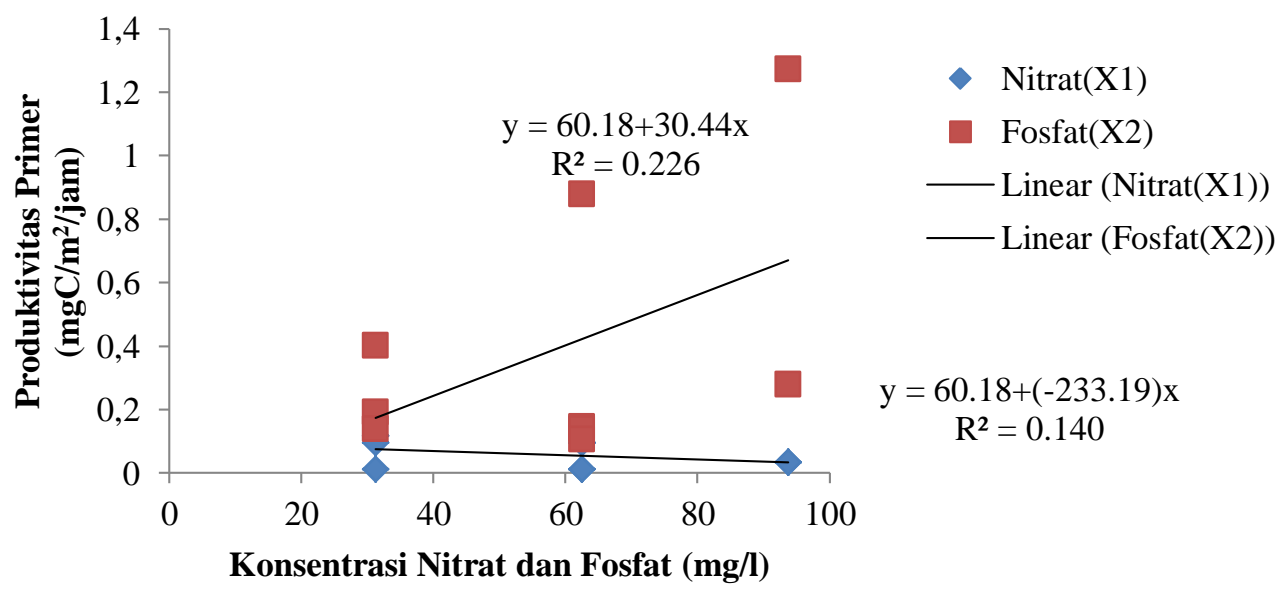

Gambar 3. Grafik hubungan konsentrasi nitrat dan fosfat terhadap produktivitas primer fitoplankton

Nilai korelasi pada hubungan konsentrasi nitrat dan fofat dengan produktivitas primer di perairan Sungai Sembilan Dumai adalah $r=0,631$. Nilai $r$ yang didapat merujuk dengan pernyataan [9] yang menyatakan bahwa apabila nilai $r$ berkisar antara 0,51 - 0,75 adalah kuat, maka untuk hubungan konsentrasi nitrat dan fosfat dengan produktivitas primer fitoplankton di perairan Sungai Sembilan Dumai adalah kuat, dapat diartikan bahwa nitrat dan fosfat mempengaruhi tingkat produktivitas primer fitoplankton yang cukup tinggi di perairan Sungai Sembilan Dumai.

\section{KESIMPULAN DAN SARAN Kesimpulan}

Berdasarkan hasil penelitian dapat disimpulkan bahwa, pengukuran kualitas perairan yang didapat menunjukkan bahwa tingkat kualitas perairan pada daerah ini tergolong baik dan masih sesuai dengan standar dari kebutuhan untuk pertumbuhan fitoplankton. Fitoplankton yang ditemukan di perairan Sungai Sembilan Dumaterdapat 6 kelas yaitu Bacillariophycae, Cocinodiscophyceae, Chroococcophyceae, Cyanophyceae, Cyanobacteria dan Xanthophyceae. Hasil perhitungan kelimpahan fitoplankton berkisar 74,07 280,09 Ind/L. Nilai produktivitas primer bersih fitoplankton berkisar antara 41,67 $72,91 \mathrm{mgC} / \mathrm{m}^{2} / \mathrm{jam}$. Sedangkan regresi linear berganda yang di dapat dengan persamaan matematis $\mathrm{Y}=60,18-233,19 \mathrm{x}$ dan $\mathrm{Y}=60,18+30,44 \mathrm{x}$ dengan nilai koefesien determinasi $\left(\mathrm{R}^{2}\right)=0,140$ dan $\left(\mathrm{R}^{2}\right)$ $=0.226$ dan koefesien korelasi $(\mathrm{r})=0,631$. Nilai $r$ yang didapat merujuk dengan berkisar antara 0,51 - 0,75 adalah kuat, dapat diartikan bahwa nitrat dan fosfat mempengaruhi tingkat produktivitas primer fitoplankton yang cukup tinggi di perairan Sungai Sembilan Dumai. 


\section{Saran}

Perlu dilakukan penelitian-penelitian dengan pembahasan yang berbeda untuk mengetahui kondisi Perairan di Sungai Sembilan Dumai, di karenakan kurangnya tingkat kesuburan yang terdapat di perairan Sungai Sembilan Dumai agar dapat menanggulangi atau mencegah menurunnya kondisi perairan tersebut.

\section{DAFTAR PUSTAKA}

1. Beranda, O.O., B. Amin, dan S.H. Siregar. 2020. The Relationship of Nitrate and Phosphate with Abudance of Epipelic in the Waters of Sungaitohor Village, regency of Meranti Island, Riau Province. Asian Journal of Aquatic Science, 2(3): 225-235.

2. Hidayat, R., S. Nedi, dan I. Nurrachmi. (2019). Analysis Concentration of Nitrate, Phosphate, Silicate and Relationship with Diatom Abudance in Waters Tanjung Tiram District Batu Bara Regency of North Sumatera Province. Asian Journal of Aquatic Sciences, 2(1): 1-11

3. Nuzapril, M., S.B. Susilo, dan J.P. Panjaitan. (2017). Estimasi Produktivitas Primer Perairan Berdasarkan Konsentrasi Klorofil-a yang Diestrak dari Citra Satelit Landsat-8 di Perairan Kepulauan Karimun Jawa. Jurnal Pengindraan Jauh, 14(1): 25-36

4. Hidayat, R., V. Lily dan A. Diana. (2013). Kajian Kandungan Klorofil-a pada Fitoplankton terhadap Parameter Kualitas Air di Teluk Tanjung Pinang Kepulauan Riau.Universitas Maritim Raja Ali Haji. Kepulauan Riau.

5. Davis, C. (1955). The Marine and Fresh Water. Michigan State University Press. New York. 562 p.

6. Yamaji, I. (1996). Illustration of Marine Plankton of Japan. Hoikusha Publishing Co Ltd. 371p.

7. Alaert, G dan S.S. Santika. (1984). Metode Penelitian Air. Usaha Nasional. Surabaya.

8. Asriyana dan Yuliana. (2012). Produktivitas Perairan. PT Bumi Aksara. Jakarta. 264 hlm

9. Tanjung, A. (2014). Rancangan Percobaan. Bandung: Tantaramesta

10. Roito, M., Y.I. Siregar, dan Mubarak. (2014) Analisis Struktur Komunitas Diatom Planktonik di Perairan Pulau Topang Kabupaten Kepulauan Meranti Provinsi Riau. Jurnal Perikanan dan Kelautan, 19(2): 22-32

11. Mustafa, A. (2015). Kandungan Nitrat dan Fosfat Sebagai Faktor Tingkat Kesuburan Perairan Pantai. Fakultas Sains dan Teknologi UNISNU Jepara. Jurnal Disprotek, 6 (1).

12. Aryawati, R. (2007). Kelimpahan dan Sebaran Fitoplankton di Perairan Berau Kalimantan Timur. Pasca Sarjana Institut Pertanian Bogor.

13. Isnaini, H. Surbakti, dan R. Aryawati. (2011). Distribusi Spasial Fitoplankton di Perairan Selat Bangka. Skripsi. Palembang: Universitas Sriwijaya.

14. Samiaji, J. (2015). Bahan Kuliah Planktonologi Laut. Fakultas Perikanan dan Ilmu Kelautan. Universitas Riau. Pekanbaru (tidak diterbitkan).

15. Melana, D., M.J. Atchue III, C.E. Yao, R. Edwards, E.E. Melana, dan H.I. Gonzales. (2000). Mangrove of Environment and Natural Resources, Manila, Philipines.

16. Nugraheni, D., M. Zainuri dan R.N. Afiati. (2014). Studi tentang Variabilitas Klorofil-a dan Net Primay Productivity di Perairan Morosari, Kecamatan Sayung Demak. Jurnal Oseanografi, 3(4): 519-527.

17. Pratama, A.D. (2019). Hubungan Total Suspended Solid (TSS) dengan Kelimpahan Fitoplankton di Perairan Selat Padang Kabupaten Bengkalis Provinsi Riau. Skripsi. Riau: Universitas Riau. 
18. Campbell, N.A., J.B. Reece, dan L.G. Mitchell. (2002). Biologi (terjemahan), Edisi kelima Jilid 3. Penerbit Erlangga. Jakarta.

19. Barus, T.A., S.S. Sinaga dan R. Tarigan. (2008). Produktivitas Primer Fitoplankton dan Hubungan dengan Faktor Fisik-Kimia Air di Perairan Parapat, Danau Toba. Jurnal Biologi Sumatera, 3(1), 11-16. 